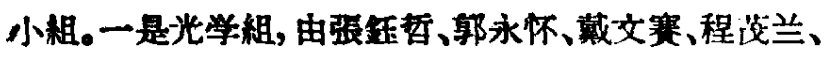

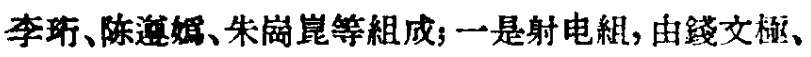
啚朔年、陈芳允、陈宗器等組成。10月14日这两个組 举行了一次联席会撞, 討論了(1)堆加光学覌測台站、 (2) 辞輯覌測手册、（3）預报人造衛星軌道通过国境 时間（4)扩大射电小組組織成員、(5)提出中苏合作 項目等問題。决定由南京紫金山天文台每天作泟衛星 在我国境內柾过路涇与时閏的預报，扑先在北京、天 津、上海、南京設立覌測站进行覌測，以后再陆續在兰 州、西安、武汉、广州、拉蒌、长春、烏鲁术齐等地没立 覌測站。在射电方面也要广泛組織收听人造衛星發出

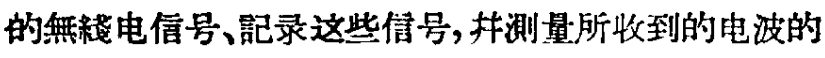
相位。

\section{[旪 明]}

\section{我国訪苏科学技术代表团、中 国科学院代表团赴苏}

国务院在今年五月間曾将我国十二年科学技术弡 展远景規划（草案）送交苏联政府，征求苏联科学家 对这个規划草案的意見。苏联政府为此業已組織了許 多著名科学家, 对这个規划草案进行了几个月的仔細 的研究和审查。現在应苏联政府的邀請，我国政府决 定組織訪苏科学技术代表团, 前往莫斯科, 听取苏联 科学家对我国十二年科学技术發展远景見划（草案） 的建議和意見，抹和茄联政府商談今后进一步加强和 全面德中苏两国的科学技术合作問題。

中华人民共和国訪苏科学技术代表团的团长为国 务院科学規划委員会副主任、中国科学院院长郭洙若。 代表团团員有: (按姓氏笔划为序)王新元(輕工業部副 部长)、刘西尧（国家技术委員会副主任）、刘涁（冶金 工菜部副部长）、汪道酒（第一机械工業部副部长）、村 潤生 (中国科学院副秘書长)、竺可楨 (中国科学院副 院长)、周唔源 (北京大学副校长)、周荣畨（建筑工程 部副部长)、范长江（国务院科学規划委員会秘書长）、 許杰 (地質部副部长)、黃松龄 (高教部副部长)、張雨 虬 (水产部副部长)、楊石先（南开大学校长）、楊显东 (农業部副部长)、錢信忠（衛生部副部长）等十五人。 代表团扭聘請了各有关产業部門和中国科学院、中国 农業科学院的六十位科学家、工程师和专家組成㕍閶 組。代表团部分团員和全体顧問已在十月中旬分批前 往苏联, 以便为代表团的正式工作做好必要推备。代 表团郭沫若团长亦在十一月二日赴苏。

与这个代表团同时赴苏的还有中国科学 院代 表 团。中国科学院代表团将和苏联科学院具体商談加强 两国科学院之間在科学研究工作上的密切联系和全面
合作等项問題，以及征求苏联科学家对我国哲学㖣会 科学十二年远景規划（草案）的意見。中国科学院代 表团成員为郭沫若（兼团长）、竺可枮、杜潤生、馮德 培、哭学周、于光远、刘导生。

\section{[瑜]}

\section{中国稻作科学技术会議}

由我国农業部主持的中国稻作科学技术会議，于 10 月 7 日至 12 日在武汉举行。这次会㦈主要是为了 交流稻作方面的科学研究成果和生产技术經驗而召开 的。参加会議的除我国稻作专家、教授和农業科学工 作者外，还有苏联、朝鮮、越南的代表。。

农業部顧大川副部长在开幕詞中指出：中国劳动 人民种稻是有很悠久的历史的，投創造了适合于南、 北、东、西各种不同环境条件下的品种和栽培方法。但 是在过去反动政权統治之下，稻的生产不能得到很好 的登展, 科学技术也不到重視。自解放以来, 在中国 共产党和人民政府的領导下，經过了土地改革，实現 了合作化，农民的生产积極性提高了，生产提高了。 1956年全国稻田播种面积占粮食作物，总播种面积 $26.8 \%$ ，比1949年堆加了11404.9万亩; 总产量占粮食总 产量 $45.2 \%$,比1949年坦加了 676.7 亿厅; 按棑地面积 計算，每亩产量已达469.8斤，井出現了不少的大面积 丰产典型一一斤县、千斤乡和千斤酒。

殿大川还指出：我們的科学研究和技术推厂 工作 也有很大的發展与提高: 优良品种的种植已有牛数, 井普遍兴修了水利; 推广了壮秋謡植; 在长江以南地 区，开展了双季連作，大力地开展了防治水稻蛽虫、 改进施肥方法等。

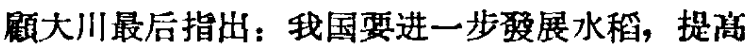
单位面积产量, 还存在一些問題, 有待今后逐步研究 解决。

这次会議收到来自全国各地的水稻专家和农㸁工 作者們所提出的論文、調查报告和經驗介紹共 21 筒， 在会上宜讀的有 14 篇。

中国农業科学院院长丁穎敉授楑过长时期的悉心 研究, 提出了題为“中国藏培稻种的起源及其演变”的 学术报告。根据我国五于年来的稻作交化例建过程， 抹由华南与泰越接連地带的野稻分布和稻作民族的重 接关系, 丁穎教授認为，我国的栽培稻种起源于华南 的野生型(Oryzae sativa L.f. Spontanea)。丁颖 授的这一諭据, 否定了过去認为我国栽培稻种是由印 度引进的說法，引起了与会者的極大注意。

除了諭述我国栽培稻和的起源以外，这筮报告还 綜迅了我国栽培槄种的最主要类型的演变与形成。根 
据米丘林关于生物与外界环境条件的統一的学說, 丁 頃院长把我国栽培稻种分成了四个不同的类型：私稉 稻型、早晚稻型、水陆稻型和粘精稻型。根据和稉在 我国各地的分布与地理环境的关系, 以及种間和种內 的特性有相当复杂的变化，他認定稉型稻种是由多型 性(Polymorphism)的稻种因气候条件，特別是因温 度条件不同的关系，而由基本型的和稻所分化形成的 气候生态型, 同时肯定了私稉是稻的两大亚种; 早晚稻 主要是因栽培季节的日照长短不同而宙私或洨型中分 化形成的气候生态型; 水陆稻是由栽培地区的田土水 分多少不同而由秈稉和早晚稻中分化形成的地土生态 型; 粘糯只是稻种特性中最明显的一个淀粉性变异形 成的栽培种型。

华东农業科学研究所哭光南、仲㢣康 在“中 国水 稻品种对光照长度反应特性的研究”这篇报告中指出, 根据我国 800 个各地不同的水稻品种对光照长度的反 应特性，明确了在各种生态条件下形成的水稻品种， 对光照长度反应的特性也有極大的差异。

由单季稻改种双季連作稻, 是长江流域地区提高 水稻单位面积产量的重要方向，也是我国稻作改制中 的創举。华东农業科学研究所捉出的“长江流域改种 双季連作稻的成就与經驗”中，論逝了长江流域的自 然条件如温度、雨量、生青期等, 說明在长江流域改种 部分单季稻为早晚連作稻是完全可能的，而且沂几年 来的試驗, 已經获得了显著的成就。

四川农学院副院长、水稻专家楊 开渠宣讀了“再 生水稻研“究”的諭文，他認为, 在条件还沒有完全具备 推广双季連作稻的地区，培育再生稻，爭取多打粮食， 仍然是相当长时期內一种过渡性的重要的增产措施。

在“水稻士中植物营养元素的生物循环 ${ }^{n}$ 一文中， 华中农学院教授陈华癸总結了过去几年中关于水稳士 中各种植物营养元素的生物循环的研究工作（主要是 中国的）; 討論了长江中下游水稻土的氧化还原势和 碳素、氮素、硫、磷、鉄等的微生物学变化; 扑且还 指出了水稻土生物循环的特点。

在水稻病害方面, 我国的农業工作者們也进行了 研究。研究者們在水稻的白叶枯病方面, 肯定了白叶 枯病在中国境內包括有两种病害: 除典型的白叶枯病 外, 在华南, 有由新种病原細菌(Xanthomonas oryzicola）所致的佃菌性条斑病; 而且两种病害的初次 感染，都以种子带菌为主要原因。

应邀参加会議的茄联、朝鮮、越南的代表，也在 会上作了报告，介紹了他們栽培水舀的經驗，受到了 参加者的热烈欢迎。茄联代表 A. П. 朱賴在他的报告 “苏联的水稻栽培及其增产途徑”中，介紹了茄联發屡 稻作的历丁史以及增产措施和良种繁育制度; 在另一篇
报告“苏联水稻灌溉系統类型及水稻栽㙔机械”中, 抳 要介紹了苏联水稻灌溉制度、灌溉定類，以及机械化载 培經驗。代表們一致認为苏联从生产出桴进行研究工 作的做法, 对我們有很大的啓墢。朝鮮代表 报告了 “关于在朝鮮推广水稻栽培技术的情况”，其中提出的 晆立式、陆休、冾休育苗等育秧方法, 在我国当前唚 展双季稻早播早插防止烂秋，流分利用生长季节的情 况下, 一致認为值得試驗和进一步研究适合我国情 况的育秋方法。越南代表报告了“越南利用 Azolla pennatc $\mathrm{R}$. 作为早稻肥料的数驗”和“稻田的复种問 題”。科学家們認为越南的复种經驗, 对今后促使 我 們更好地总結和制訂一套适于我国自然与經济条件的 水稻輸作制度有很大的啓没。

会議閔幕时各国代表一致表示今后要加强各国間 水稻科学趼究工作的紧密联系, 以促进各国水稻技术 工作的迅速發展与高提。

\section{〔孔乡 乡}

\section{我国物理学家本政道、楊层宁 获得今年的諾貝尔物理学奖金}

我国留美物理学家李政道和楊振宁, 由于在 “字 称守恒定律” 方面的重要發現，获得了今年的諾貝尔 物理学奖金。这是我国科学家第一次获得諾貝尔奖金。 我国物理学家吳有訓、周培源、錢三强代表中国物理学 会給他們拍去了賀电。

\section{[叶英]}

\section{参加苏联声学会議的报告}

全苏声学会議一般是每两年召开一吹, 这次是本 年 6 月24-29日开的, 由茄联科学院声学委員会、声 学研究所和莫斯科大学联合召集的, 全苏各地到莫斯 科参加会議的声学专家有二百多人，会議还邀請了民 主德国、波兰、匈牙利、捷克、丹麦和我国的学者渗加， 是声学界的一次盛会。会議的內容是: 不均匀媒質中 声波傳播問題、声波的發射和衍射、有限振幅声波、超 声物理、音乐声学、生理声学、和語言研究等 7 个方 面。过去已开过全国性电声学的专門会議（㚏加的也 有 200 人以上), 本年 4 月關还开过一次全国性超声技 术的专門会議, 因此这次会議中就没有那些內容了。

会議上提出的論文报告共約 140 篇，参加会議的 外国科学家也都作了报告。全体大会开过 3 次，按以 上 7 个方面开过的分組会共 31 次, 由于許多分組会是 同时开的，一个人除了参加大会外，分組会只能部分 地参加, 我国代表只作者一人, 情况就是如此。 